$\begin{array}{r}\begin{array}{c}\text { Interdisciplinary Contexts of Special Pedagogy } \\ \text { NUMBER } 31 / 2020\end{array} \\ \text { MIROSŁAW MIELCZAREK }{ }^{1} \\ \text { University of Lower Silesia, Poland } \\ \hline\end{array}$

\title{
Preparation of socially maladjusted youth located in youth educational centres for self-sufficient living
}

\begin{abstract}
Mirosław Mielczarek, Preparation of socially maladjusted youth located in youth educational centres for self-sufficient living. Interdisciplinary Contexts of Special Pedagogy, no. 31, Poznań 2020. Pp. 361-377. Adam Mickiewicz University Press. ISSN 2300-391X. e-ISSN 2658-283X. DOI: https://doi.org/10.14746/ikps.2020.31.17
\end{abstract}

The article is of a theoretical and research nature. The theoretical part outlines the specificity of a social rehabilitation centres for minors and refers to the definition of self-sufficiency. The subject of the research was the empowerment of juveniles staying in youth educational centres. Their aim was to find out the answer to the problem: what methods and forms of work are used by youth educational centres to prepare minors for a self-sufficient life after leaving them in the following spheres: family, professional, social and civic? The project was carried out in three selected youth educational centres. The data was obtained using the pedagogical monograph method, for which the document analysis technique was selected, supplemented with an original data sheet acting as a research tool. The research was conducted in the mainstream of the qualitative approach identified with the interpretative paradigm, which allowed for the abandonment of hypotheses.

KEY WORDS: minors, socially maladjusted youth, self-sufficiency, preparation for self-sufficient life, youth educational centre

${ }^{1}$ Mgr Mirosław Mielczarek - University of Lower Silesia, PhD student, pedagogue with a speciality in care and rehabilitation, years of practical experience in care and educational work, as well as, rehabilitation both with youth and adults, Stara Brzeźnica ul. Częstochowska 102, pp. 98-331, e-mail: mirek91.m@gmail.com. 


\section{Introduction}

Socially maladjusted youth is defined as minors in Polish law.

According to the minor case act, the term will refer to persons who':

- are not of 18 years of age, to which demoralisation prevention and combating rules apply;

- to persons who have committed a penal crime after finishing 13 years of age, but have not finished 17 years of age;

- to persons who have not finished 21 years of age, to which educational or correctional measures were adjudged.

The court may apply educational measures and the most severe - the correctional measure, by placing individuals in a correctional facility. One of the educational measures at court disposal, is to place an individual in a Youth Educational Centre (Młodzieżowy Ośrodek Wychowawczy - MOW). The indicated facility is a part of the institutional system of rehabilitation of minors, where socially maladjusted youth is directed. The role of the central system of directing youth to youth educational centres is played by the Education Development Centre (Ośrodek Rozwoju Edukacji - ORE) in Warsaw. ${ }^{3}$ Youth educational centres are dedicated to children and youth that require special learning organisation, work methods and education. ${ }^{4}$ Socially maladjusted youth is burdened with a high risk of social exclusion. ${ }^{5}$ They are individuals who have difficulty in establishing and maintaining interpersonal relations and functioning in particular roles.

2 Minor case act, Journal of Laws of 1982, no. 35, pos. 228 with further changes, art. $1, \S 1$.

${ }^{3}$ D. Kukla, M. Mielczarek, Przygotowanie młodzieży niedostosowanej społecznie do samodzielności zawodowej w młodzieżowych ośrodkach wychowawczych, "Problemy Opiekunczo-Wychowawcze" 2020 - after review, in print.

${ }^{4} \mathrm{M}$. Kranc, Metodyka procesu resocjalizacji w młodzieżowych ośrodkach wychowawczych, Oficyna Wydawnicza “Impuls”, Kraków 2018, p. 17.

${ }^{5}$ K. Konaszewski, Ł. Kwadrans, Zasoby osobiste młodzieży nieprzystosowanej społecznie. Uwarunkowania środowiskowe, Oficyna Wydawnicza "Impuls", Kraków 2018, p. 46. 
The essence of the activity of educational centres is to eliminate causes and manifestations of social maladjustment in minors, allowing them to acquire education, upbringing in the feeling of responsibility, as well as, teaching patriotic and pro-social values. It is also the ensuring of secure conditions for learning and upbringing, preparing for a self-sufficient life in accordance with universal legal or social norms. Youth educational centres are usually open. In their structure, they resemble universally available boarding schools. However, staying in them is related to the limitation of freedom and a certain level of isolation from the external environment. Minors have limited contact with peers from outside of the institution, as well as their freedom to leave the designated area. Institutions of such type are highly formalised, meaning that staying at them is regulated by proper prescriptions such as: statutes, instructions, educational programmes, activity schedules. ${ }^{6}$ Within the educational centres, there are numerous schools operational such as elementary, vocational (following the reform), technical, and high schools. ${ }^{7}$ The employees consist of varying staff: management, pedagogical (educators, teachers), psychologists, therapists, a social worker, nurse, and special curricula instructors. ${ }^{8}$ Since 2004 , youth educational centres have been under the competencies of the Ministry of National Education, after claiming them from the social policies department.

Each rehabilitation institution form minors conducts process of making pupils self-sufficient. The same occurs in youth educational centres. The majority of scholarly sources dedicated to the subject is

${ }^{6}$ B. Stańkowski, Efektywność resocjalizacji w salezjańskich Młodzieżowych Ośrodkach Wychowawczych w Polsce, Wydawnictwo Naukowe Akademii Ignatianum w Krakowie, Kraków 2018, p. 31.

7 J. Siemionow, Rola i zadania pracownika socjalnego w Młodzieżowym Ośrodku Wychowawczym, [in:] M. Teodorczyk (ed.), Widzieć, rozumieć, pomagać. Przykłady rozwiazań stosowanych w codziennej pracy pracownika socjalnego, Centrum Rozwoju Zasobów Ludzkich, Warszawa 2013, pp. 104-105.

8 T. Kaniowska, Funkcjonowanie młodzieżowych ośrodków wychowawczych $i$ mtodzieżowych ośrodków socjoterapii w systemie oświaty, „TRENDY” 2015, no. 4, pp. 13-15. 
focused on the institutional and legal aspects of preparing youth for life self-sufficiency. Much less attention was directed towards research analysing individual preparation of the pupils to leave the facility or on the methods and forms of pedagogical work that serve the aforementioned purpose. The following research fill this gap to a certain degree, as they encompass methods and forms of working with minors, that are performed in youth educational facilities in the process of making them self-sufficient.

\section{Preparing for a self-sufficient life}

Preparing the socially maladjusted youth to lead a self-sufficient live after leaving the facility is the final result of rehabilitation efforts. It is a long-lasting process tied to the system of specialist legal and educational actions, aiming at socialising the pupil. ${ }^{9}$ It begins from the moment of accepting the minor to the institution, and lasts until the individual leaves the facility. Then, deliberate actions of educators and rehabilitation personnel, aiming at the pupil to reach self-sufficiency in the open environment are being taken. The preparation for life self-sufficiency is one of the key elements of the socialisation process. Without a doubt the process is incredibly complex, necessary and important. ${ }^{10}$ Teaching the socially maladjusted youth, the basic features allowing to function self-sufficiently, is a difficult process, as it takes place in a closed environment. Such path is taken i.a. by pupils of the youth educational centres.

The pupils of rehabilitation institutions for minors often struggle with numerous severe disorders and shortcomings, that may pre-

${ }^{9}$ I. Motow, D. Janułajtys, Perspektywa skutecznej resocjalizacji nieletnich w kontekście procesu usamodzielnienia, [in:] M. Walenciak, J. Hroncowa (eds.), Pedagogika społeczna wobec procesów żywiołowych i zachowań ryzykownych, Wydawnictwo Edukacyjne „Akapit”, Torun 2013, p. 375.

${ }_{10}$ M. Mielczarek, Przygotowanie do samodzielności życiowej usamodzielnianych wychowanków placówek opiekuńczo-wychowawczych, "Civitas Hominibus” 2018, no. 13, p. 159. 
vent them from achieving self-sufficiency. The process of making the pupils self-sufficient in facilities should be characterised by actions supportive for their social reintegration, for their continued education, for building motivation, and preventing social exclusion. ${ }^{11}$ Literature uses various approaches towards self-sufficiency, which indicates that the term may be interpreted in many ways. In behaviouristic theory, self-sufficiency is defined as the ability allowing an individual to perform certain actions regardless of the surroundings. It is shaped in result of social contacts and is identified with habit, as independent behaviour is approved by the environment and rewarded, which encourages repetition. In the humanistic theory, a self-sufficient individual performs actions to accomplish own aims, motivated by individual motives. Self-sufficiency perceived as such is related to responsibility, self-control, but also requires perseverance and the ability to deal in difficult situations. A slightly different approach is presented in cognitive theories. There, self-sufficiency is defined as acquiring experience during the entire lifespan. Individual experiences of an individual serve its development and predispose the individual towards particular actions. ${ }^{12}$

Self-sufficiency often spawns associations with self-service skills, however, it is much more worth to discuss its aspects in a much broader context. The proper understanding seems to be that, which treats it as autonomy in all spheres of the individual's functioning, independence from others within the limits of own predispositions, as well as, the ability for self-determination. On the other hand, self-sufficiency should not be identified with an assortment of competencies useful in action, but examined as a certain developmental mechanism. ${ }^{13}$ The concept of self-sufficiency is identified with au-

${ }^{11}$ M. Dobijański, A. Kamiński, Niedostosowanie społecznie nieletnich. Profilaktyka i resocjalizacja, Uniwersytet Przyrodniczo-Humanistyczny w Siedlcach, Siedlce 2020, p. 116.

${ }^{12}$ D. Domagała, Postrzeganie samodzielności przez uczniów klas trzecich uczacych się wedtug koncepcji planu daltońskiego, „Problemy Opiekuńczo-Wychowawcze” 2019, no. 1 , p. 37.

${ }^{13} \mathrm{H}$. Kubiak, Samodzielność matych dzieci z porażeniem mózgowym, Wydawnictwo UAM, Poznań 2011, p. 17. 
tonomy, maturity, independence and the ability to lead an independent life. Self-sufficiency is one of many features that are included within the personal structure. ${ }^{14}$ It is intuitively perceived not only as a certain personality feature. Additionally, it results from the internal need of independent acquiring and gathering life experiences, necessary for the individual. Striving for self-sufficiency contributes to learning own limitations and capabilities. Achieving it is related to the ability to take responsibility and suffer consequences for own actions. ${ }^{15}$ For the study, we adopted the understanding of self-sufficiency following G. Gajewska. According to the premises, a self-sufficient individual is characterised by the appropriate preparation for family, professional, social and civic life. ${ }^{16}$ The categories listed are the four basic tasks, that should be realised by an institution in order to help the pupil to achieve self-sufficiency.

\section{Methods}

The object of performed study is the process of making minors self-sufficient, that are place in youth educational centres. The aim of the study was to learn the answer to the problem posed in the question object: what methods and forms of work are employed by youth educational centres in order to prepare minors for a self-sufficient life after leaving the facilities in spheres: family, professional, social and civic? The research procedure assumes a qualitative strategy associated with the interpretative paradigm, allowing to resign from hypotheses. ${ }^{17}$ The realisation of research used the peda-

14 D. Ruszkiewicz, Samodzielność życiowa dorostych córek nadopiekuńczych ojców, „Pedagogika Rodziny” 2018, no. 8(1), p. 88.

15 Z. Woźniak, Samodzielność życiowa osób z lekkq i umiarkowana niepełnosprawnościa intelektualna w świetle danych uzyskanych za pomoca nowego narzędzia pomiaru, „Niepełnosprawność i Rehabilitacja” 2017, no. 3, p. 63.

16 G. Gajewska, Pedagogika opiekuńcza i jej metodyka, Wydawnictwo Naukowe Uniwersytetu Zielonogórskiego, Zielona Góra 2004, p. 109.

17 T. Pilch, T. Bauman, Zasady badań pedagogicznych. Strategie ilościowe i jakościowe, Wydawnictwo Akademickie „Żak”, Warszawa 2001, p. 279. 
gogical monograph method, complemented by the document analysis technique. The research tool was based on the original data chart in form of a table, assorted of four parts considering the preparation for self-sufficiency: family, professional, social and civic. The constructed tool served the purpose of noting information from resource materials (educational work schedule, reports from centres' activities, archive documents). Studies were performed at the brink of May and June 2019 in three youth educational centres located in: Kraków, Radzionków, Namysłów. The selected centres are dedicated to socially maladjusted youth within the intellectual aspect. Two of them included girls (Kraków, Radzionków), while boys in one (Namysłów). The centres located in Kraków nad Namysłów have a non-public status, while the Radzionków facility is public. During the study, the personnel was deliberately not informed regarding what self-sufficiency areas would be subject to analysis.

\section{Results}

The process of self-sufficiency establishment in the Radzionków Youth Educational Centre is realised on the basis of broadly perceived self-governance and self-sufficiency of the pupils. The centre's staff would come to conclusions, that a restrictive system based on punishments and rewards with difficult youth is ineffective, and, moreover, its effects last short and expire when the restrictions cease. The model applied in Radzionków serves the purpose of integrating educational actions within the area of re-adaptation to the social environment.

The effort taken is to correct improper and hazardous social attitudes of the minors, develop skills in terms of interpersonal relations, improve faith in own abilities and self-assessment, nullify the demanding attitude, develop the feeling of responsibility and awareness in terms of controlling own fate. The work is realised based on independent educational groups, pupils' community, local government, collaboration with minors' parents and support institutions. 
The primary programme premises regarding working with groups of achieving self-sufficiency in the Radzionków Youth Educational Centre are based on developing the girls' ability to function independently in society, in family, and particularly:

- the development of the ability to independently organise own living conditions: independent management of financial resources, cooking, task planning and accomplishment, related to everyday living needs (groceries, keeping the living space clean);

- development of interpersonal relations necessary in everyday social life, particularly related to the optimisation of interhuman relations, assertiveness, proper communication, conflict solving;

- shaping the ability to evaluate own resources and limitations, developing self-awareness and acquiring the ability to independently create own development, particularly in areas such as: learning and using own resources, selecting social and emotional models, developing motivation for changing unfavourable models, developing independency in decision processes, taking responsibility for own choices.

To a certain degree, the self-sufficiency group, allows for self-sufficient household management. Minor females that remain in such groups have a monthly food budget at their disposal. Along with the educator, the pupils plan their weekly menu and independently make purchases of the groceries. The group has its own kitchen at disposal, where they make their own meals. This creates the potential to acquire skills of managing a household in a self-sufficient manner. This way of functioning allows to shape the skills of planning, cooperation, and moreover, it shapes responsibility attitudes. Minors are taught to spend their funds rationally, segregate waste, save energy, water, food, and are familiarised with the rules of healthy feeding. The task of the educator is to provide partner support, aid in tasks to be accomplished, and in difficulties encountered, to give hints, and strive to create an atmosphere of cooperation and kindness. 
In preparation for self-sufficiency it is also important to strengthen the hobbies of pupils. In the centre indicated, it is being accomplished by encouraging reading youth literature and press, participation in hobby groups organised on-site, cooperation of minors in editing the centre newspaper, watching entertainment and information programmes. Minors are encouraged to participate in voluntary work and to take up income work as a possibility to interact with the environment. Additionally, motivation is deployed for the pupils to work for the good of the local society, supporting and helping in taking up extracurricular trainings and courses in order to improve personal competencies.

Minors from the Radzionków centre participate in individual activities from the programme titled "My first step on the labour market" and "ZnajdźPracę.pl". The activities features such as: recognising own traits and hobbies, the analysis of own potential (weaknesses and strengths, values and expectations), the development of interpersonal communication, acquiring skills of stress and change management, overcoming own weaknesses and limitations, shaping of the ability to make decisions, the development of positive thinking and self-acceptance, shaping the ability for self-presentation. Additionally, the activities help in learning different forms of employment, indicate the sources to look for employment, they teach how to establish contact with the employer, and how to deal during a job interview. The pupils receive information regarding the employment market, how to establish own company, and learn the rights and obligations of an employee, and are presented with employment cards.

The girls learn approximate knowledge regarding civil rights and obligations. During their stay at the centre, they participate in meetings with employees of the Couinty Centre for Family Aid, County Labour Office, Voluntary Labour Corps, Police and State Fire Service, in order to familiarise them with the specifics of these institutions' operations. Minors participate in the "Closer to democracy" action along with other local educational institutions and are observers of the Radzionków City Council proceedings. Minors 
participate in local patriotic holidays (co-organisers of the Wujek Coal Mine pacification).

The Kraków Youth Educational Centre, also referred to by the staff as the House of Charity, also conducts different actions towards the girls, coherent with the adopted rehabilitation model. These actions aim to discover values, talents, develop hobbies and prepare minors for proper and self-sufficient life in the society. Implementing proper behaviour and attitudes among the pupils is supported by rewarding them in various forms. The leading aims of educational actions in the centre are as follows:

- correcting improper behaviour and attitudes;

- shaping of personal culture;

- shaping of proper social, patriotic and moral attitudes;

- teaching planning, organisation and a systematic approach;

- shaping of proper interpersonal attitudes;

- training for health prophylaxis;

- recognising and developing talents and hobbies;

- shaping an open attitude towards figures of authority;

- preparing for a self-sufficient life.

The aims are accomplished via the following forms:

- systematic and persistent self-teaching;

- organisation shifts (daily care for cleanness, hygiene and order);

- participation in works of sections and hobby clubs;

- common celebration in groups and in the House of Charity community, during centre celebrations;

- physique care;

- accomplishing self-sufficiency tasks (professional pre-orientation "towards adulthood", "tasks" voluntary work);

- integration and recreation meetings;

- meetings with guests - interesting persons;

- shaping the skills useful in a self-sufficient life.

Achieving self-sufficiency, as in any other centre, is the final phase of the rehabilitation process, aiming at preparing the pupils to undertake a self-sufficient life in the society and to properly function in the basic social roles. In the Kraków institution, it is accom- 
plished by the accomplishment of defined development aims. One of them is to prepare the girls for functioning in various feminine roles with dignity (daughter, sister, colleague, wife, mother).

The next area is to prepare pupils for the proper functioning in professional roles. It is conducted via psychological study and professional direction within the scope of the professional pre-orientation programme. There are group workshops "towards adulthood", specialist (computer, gastronomy), driver's licence, stained glass, and glass mosaic courses.

In turn, preparation for the proper functioning in social roles is accomplished via various training of social skills (interpersonal communication, assertiveness, cooperation and negotiation, constructive means of conflict solving, health prophylaxis, abstinent behaviour, knowledge of particular office procedures and how to perform them swiftly in basic offices and state institutions). Additionally, it aims at teaching pro-social attitudes, altruistic, through working voluntarily for sick children, the lonely and the elderly.

In the Kraków centre, the process of achieving self-sufficiency of pupils is divided into certain essential phases (forms of influence):

- self-governance days: intelligent planning and organisation of the day that is free from school activities, considering the time for rest, learning and developing own hobbies;

- independent leaves aiming at accomplishing a particular task (official works, visits at specialists clinics, shopping, movie theatre, voluntary workplaces, at times - visits at family homes);

- taking care of a younger colleague (filling the "Angel" role), in order to ensure support and aid for the newly arrived colleague ("Soul");

- participation in the professional mobilisation programme "Towards adulthood" (researching the traits towards performing a particular profession);

- voluntary work allowing to shape social skills, group collaboration, empathy and sensibility for the needs of a second human being; 
- shaping of additional skill useful in self-sustainable life (cooking, driver's license, language courses, computer);

- providing support to a self-sufficient person (supportive work, intervention and crisis action in different life situations).

Additionally, at the Kraków institution, there are two self-sufficiency houses, that look no different from the entire infrastructure. They are situated among private family houses near the original centre. There, minors reside - those who are past 17 years of age and their behaviour yields no reason for doubt. In each group there is a shift educator, who is to support the minors. The house of selfsufficiency is equipped in all necessary daily items. The girls have their own budget, and prepare meals by themselves. Each minor may be taken back to the central location of the centre for inappropriate behaviour.

The Kraków centre staff assumes that it is also important to support graduates who made themselves self-sufficient. There are numerous cases, when a given graduate requires help and often uses various forms of support from the directorial board and the pedagogical group. The forms of support include: visits, letters, telephone calls, occasional meetings, the possibility to continue spiritual formation (retreat participation), support in crisis situations, participation in weddings or christening ceremonies.

The final institution where the study took place is the Namysłów Youth Educational Centre. The rehabilitation actions that take place there also aim at preparing male youth to leave the institution. To a large degree, they are coherent with those undertaken with two previous centres, but with females:

- independent cooking (kitchen organisation, meal preparation, preparing the menu, buying and managing the food products, learning to use the kitchen appliances, the aesthetics of serving meals);

- learning to use appliances (washing machine, drier, iron), learning the principles of clothing segregation, adjusting the temperature of washing, and agents, acquiring appropriate knowledge regarding safety while using electronic devices, instruments during performing small household tasks; 
- hygiene and order;

- preparation of pupils to fulfil social roles (husband);

- taking care of tasks in offices and institutions (teaching to navigate within public benefit institutions and acquiring the skills in terms of acquiring allocation of a dwelling, checking in, issuing documents and material assistance);

- teaching to functioning on the employment market, including self-learning, increasing qualifications, developing hobbies;

- preparation to deal in difficult situations, conflict solving, acquiring the skill to express own feelings and views in a manner that would not infringe the boundaries of other persons, as well as, without the use of aggression, acquiring the ability to independently decide on important things, and to make life important decisions consciously;

- participation in various charity actions;

- teaching the pupils about institutions that support the selfsufficient process: GOPS, MOPS, PCPR, MOPR;

- participation in works for the local community;

- participation in the cultural and educational life;

- strengthening the feeling of national identity, the ties to history and national traditions;

- encouraging participation in patriotic events;

- shaping civic attitudes;

- shaping attitudes towards respecting the tradition and culture of own nation;

- helping to realise that education is a life-long effort.

In the centre located in Namysłów, there was no separate selfsufficiency group, as boys who were place there have been, for a long time, between 17 and 18 years of age. They are minors who have usually experienced being placed in different institutions, and they were relocated to finish the previously initiated phase of education. In result of such proceeding, all pupils are subject to intensive self-sufficiency actions on the educational and legal levels. 


\section{Summary}

The material gathered allowed to learn the methods and forms of work applied in three youth educational centres, in order to prepare the socially maladjusted youth to a self-sufficient life after leaving. The analysed documentation shows, that the institutions would undertake actions within the scope of the self-sufficiency process, that were related to the following aspects: family, professional, social, civic. The applied methods and forms of rehabilitation work in the examined centres were not essentially different. Analysing the documentations, many obstacles were faced in order to distinguish particular rehabilitation actions. The effort itself may seem mislead, as the lack of the distinction of particular areas may result in omitting the key ones.

Preparation for family self-sufficiency was conducted via thematic workshops, teaching how to function as: mother, father, daughter, sibling, husband, wife. Household courses were organised, using testimonies of different persons who established families. In order to achieve professional self-sufficiency, the aforementioned centres would train primarily on the level of vocational schools and technical schools within a given profession. Moreover, institutions organised courses to improve professional qualifications of the pupils, participated in projects regarding vocational counselling, research was made regarding professional pre-orientation. The centres' staff also encouraged minors to undertake work in their spare time. Preparation for social life was most often accomplished by managing own funds, cooking, shopping planning, teaching personal hygiene principles, keeping in order, conducting trainings in interpersonal skills, independent office chores, as well as, voluntary work participation. In the civic sphere, the minors were introduced to civic rights and obligations, encouraged to participate in state celebrations, and taught the history of Poland.

Preparing to establish a family, selected institutions would primarily encourage minors to participate in voluntary work. The proper places to realise that are the lonely mother houses, care and 
education institutions (orphanages), and social aid homes. Spending time in such centres may teach empathy, care, contact with children, elders, the sick, persons in need, as well as, shapes social skills necessary in adult life. An essential solution, the aim of which was to prepare girls for motherhood was applied in the Correctional Facility and Shelter for Minors in Zawiercie. The facility equipped the girls that were striving for self-sufficiency, with simulators that would imitate a child. Each "doll” was programmed so that it would display cry, hunger, the need to change diapers, rocking or closeness, Such project may be conducted successfully among youth educational centres, including boys. The pedagogical staff, while preparing individuals for self-sufficient family life should present to their pupils, what attitudes of their parents are worth of imitating and what are not. The aspect of preparing minors for vocational activity is present already in the phase of directing an individual to an institution by ORE. There cannot be a situation, when a pupil is placed in a given facility only due to there being a vacancy with omission of their individual professional traits. Indicating the location, should be preceded by the examination of professional preorientation. The subsequent step is the choice of a proper rehabilitation institution corresponding with test results. Preparation for a self-sufficient social life, as the entire self-sufficiency process is best to be accomplished by creating small heterogeneous groups, implementing family systems, and isolate self-sufficiency groups. Such system allows to individualise educational actions and encourage pupils to undertake independent actions (e.g. shopping, preparing meals, menu planning, official business, managing the budget). Unfortunately many institutions do not decide in favour of creating self-sufficiency groups due to infrastructural and financial reasons. On the other hand, preparation for civic self-sufficiency is often associated with general social functioning, therefore, treated marginally and casually. Regardless, the area may be accomplished by: daily screening of informational programmes (several at best, in order to examine many viewpoints), celebrating national holidays, and indicating differences between them and church holidays, read- 
ing and analysis of the Polish Constitution, encouraging to participate in state holidays, displaying the flag together with pupils, encouraging them to participate in the election, not promoting own political views in front of the pupils, and allowing them to develop their own opinion.

Preparing a rehabilitation institution pupil for self-sufficient life, one must remember, that in time he will become an independent citizen. It is the institution, that will influence what citizen he will be. The selection of appropriate methods and forms is key. Legal regulations allowing to receive financial aid are of importance. However, one must remember, that the ability to gain aid for self-sufficiency, and its rational spending afterwards, is connected to proper initial preparation within the institution.

\section{References}

Dobijański M., Kamiński A., Niedostosowanie społecznie nieletnich. Profilaktyka i resocjalizacja, Uniwersytet Przyrodniczo-Humanistyczny w Siedlcach, Siedlce 2020.

Domagała D., Postrzeganie samodzielności przez uczniów klas trzecich uczacych się wedtug koncepcji planu daltońskiego, „Problemy Opiekuńczo-Wychowawcze” 2019, no. 1, pp. 36-43.

Gajewska G., Pedagogika opiekuńcza i jej metodyka, Wydawnictwo Naukowe Uniwersytetu Zielonogórskiego, Zielona Góra 2004.

Kaniowska T., Funkcjonowanie młodzieżowych ośrodków wychowawczych i młodzieżowych ośrodków socjoterapii w systemie oświaty, „TRENDY” 2015, no. 4, pp. 13-17.

Konaszewski K., Kwadrans Ł., Zasoby osobiste młodzieży nieprzystosowanej spotecznie. Uwarunkowania środowiskowe, Oficyna Wydawnicza „Impuls”, Kraków 2018.

Kranc M., Metodyka procesu resocjalizacji w młodzieżowych ośrodkach wychowawczych, Oficyna Wydawnicza „Impuls”, Kraków 2018.

Kubiak H., Samodzielność małych dzieci z porażeniem mózgowym, Wydawnictwo UAM, Poznań 2011.

Kukla D., Mielczarek M., Przygotowanie młodzieży niedostosowanej spotecznie do samodzielności zawodowej w młodzieżowych ośrodkach wychowawczych, „Problemy Opiekuńczo-Wychowawcze" 2020 - after review, in print.

Mielczarek M., Przygotowanie do samodzielności życiowej usamodzielnianych wychowanków placówek opiekuńczo-wychowawczych, „Civitas Hominibus” 2018, no. 13, pp. 159-168. 
Motow I., Janułajtys D., Perspektywa skutecznej resocjalizacji nieletnich w kontekście procesu usamodzielnienia, [in:] M. Walenciak, J. Hroncowa (eds.), Pedagogika społeczna wobec procesów żywiotowych $i$ zachowań ryzykownych, Wydawnictwo Edukacyjne „Akapit”, Torun 2013, pp. 375-387.

Pilch T., Bauman T., Zasady badań pedagogicznych. Strategie ilościowe i jakościowe, Wydawnictwo Akademickie "Żak”, Warszawa 2001.

Ruszkiewicz D., Samodzielność życiowa dorostych córek nadopiekuńczych ojców, „Pedagogika Rodziny" 2018, no. 8(1), pp. 87-98.

Siemionow J., Rola i zadania pracownika socjalnego w Młodzieżowym Ośrodku Wychowawczym, [in:] M. Teodorczyk (ed.), Widzieć, rozumieć, pomagać. Przykłady rozwiazań stosowanych w codziennej pracy pracownika socjalnego, Centrum Rozwoju Zasobów Ludzkich, Warszawa 2013, pp. 104-115.

Stańkowski B., Efektywność resocjalizacji w salezjańskich Młodzieżowych Ośrodkach Wychowawczych w Polsce, Wydawnictwo Naukowe Akademii Ignatianum w Krakowie, Kraków 2018.

Minor case act, Journal of Laws of 1982 r., no. 35, pos. 228 with further changes.

Woźniak Z., Samodzielność życiowa osób z lekkq i umiarkowanq niepetnosprawnościq intelektualna w świetle danych uzyskanych za pomoca nowego narzędzia pomiaru, „Niepełnosprawność i Rehabilitacja” 2017, no. 3, pp. 63-72. 